\title{
Establishing the link between Ostreopsis cf. ovata blooms and human health impacts using ecology and epidemiology
}

\author{
Magda Vila ${ }^{1}$, Rafael Abós-Herràndiz ${ }^{2}$, Jordi Isern-Fontanet ${ }^{1}$, Josep Àlvarez ${ }^{3}$, Elisa Berdalet ${ }^{1}$ \\ ${ }^{1}$ Institut de Ciències del Mar, CSIC, Passeig Marítim de la Barceloneta, 37-49. E-08003 Barcelona, Catalonia, Spain. \\ E-mail: magda@icm.csic.es \\ ${ }^{2}$ Catalan Health Institute, Department of Primary Health Care, Generalitat de Catalunya, CAP Carles I, Carrer Marina 168, \\ E-08013 Barcelona, Catalonia, Spain. \\ ${ }^{3}$ Public Health Agency of Catalonia, Department of Health, Generalitat de Catalunya, Carrer Roc Boronat 81-85, E-08005 \\ Barcelona, Catalonia, Spain.
}

M.V. and E.B. contributed equally to the manuscript.

\begin{abstract}
Summary: Blooms of the benthic dinoflagellate Ostreopsis have been related to sporadic acute respiratory symptoms and general malaise in people exposed to marine aerosols on some Mediterranean beaches. However, the direct link between recurrent Ostreopsis blooms and health problems has not been clearly established. In order to establish and elucidate the connection, we conducted a joint ecology and epidemiology study in an Ostreopsis hot spot. Throughout the bloom, which extended from the end of June until the end of October 2013, $81 \%$ of the human cohort that we studied experienced at least one Ostreopsis-related symptom. Paradoxically, the time when the effects were greatest was during a short time window in early August. This corresponded to the transition from the exponential growth to the stationary phase of the bloom. Negligible symptoms were reported from August to mid-October, during the stationary period of the proliferation, when $O$. cf. ovata maintained high concentrations of epiphytic cells. No clear patterns in the landward wind component were noted during the time when health effects were greatest. Our main hypothesis is that the irritants present in the aerosol are produced during a particular physiological phase of the Ostreopsis cells during the bloom.
\end{abstract}

Keywords: Ostreopsis, epidemiology, Mediterranean, HAB, dinoflagellates, respiratory irritation.

Aproximación ecológica y epidemiológica para establecer la relación entre las proliferaciones de Ostreopsis cf. ovata y sus impactos sobre la salud humana

Resumen: Las proliferaciones del dinoflagelado bentónico Ostreopsis en algunas playas del Mediterráneo se han relacionado con síntomas respiratorios agudos esporádicos y malestar general en las personas expuestas a los aerosoles marinos. Sin embargo, la relación directa entre las proliferaciones recurrentes de Ostreopsis y los problemas en la salud no ha sido claramente establecida. Con el fin de establecer esta conexión se realizó un estudio ecológico y epidemiológico conjunto en una playa afectada por dichos eventos. A lo largo de la proliferación, que se extendió desde finales de junio hasta finales de octubre de 2013 , el $81 \%$ de la cohorte humana estudiada presentó al menos un síntoma relacionado con los potencialmente producidos por Ostreopsis. Paradójicamente, la mayoría de los efectos se produjeron durante un breve período de tiempo, a principios de agosto, coincidiendo con la transición de la fase de crecimiento exponencial de la proliferación a la fase estacionaria. A partir de agosto y hasta mediados de octubre, durante dicha fase estacionaria en que se mantuvieron concentraciones elevadas de $O$. cf. ovata, los síntomas fueron negligibles. Durante el período de tiempo con mayor afectación en la salud, no se observó un patrón claro en la componente de viento de mar hacia tierra. Nuestra hipótesis principal es que los compuestos irritantes presentes en el aerosol se producen durante una fase fisiológica particular de las células de Ostreopsis en un momento concreto de la proliferación.

Palabras clave: Ostreopsis, epidemiología, Mediterráneo, proliferaciones algales nocivas, dinoflagelados, irritaciones respiratorias.

Citation/Como citar este artículo: Vila M., Abós-Herràndiz R., Isern-Fontanet J., Àlvarez J., Berdalet E. 2016. Establishing the link between Ostreopsis cf. ovata blooms and human health impacts using ecology and epidemiology. Sci. Mar. 80S1: 107-115. doi: http://dx.doi.org/10.3989/scimar.04395.08A

Editor: D. Vaqué.

Received: December 29, 2015. Accepted: April 29, 2016. Published: September 30, 2016.

Copyright: (9 2016 CSIC. This is an open-access article distributed under the terms of the Creative Commons Attribution (CC-by) Spain 3.0 License. 


\section{INTRODUCTION}

At the beginning of the 21st century the blooms of the toxic benthic marine dinoflagellate genus $O s$ treopsis Schmidt appeared as an emerging potential threat to human health in Mediterranean coastal areas. This microalga of tropical origin that produces palytoxin (PLTX; Rossi et al. 2010) and associated analogues has been blooming recurrently at some locations in the Mediterranean during the last 20 years (e.g. Vila et al. 2001, Aligizaki and Nikolaidis 2006, Mangialajo et al. 2011). Its presence was previously detected in tropical and temperate coasts of Australia, the Indian Ocean, eastern Asian, the Caribbean sea, Brazil and, in the last decade, in colder waters of the northern Sea of Japan, New Zealand, Portugal, the Atlantic coasts of France and Spain (e.g. Selina and Orlova 2010, Rhodes 2011 and references therein). This apparent increased occurrence in both temperate and tropical regions (Rhodes 2011) has also been noticed with other harmful microalgae. It is not yet clear whether this is due, in part, to improved detection and monitoring capacity or whether the combination of global warming and anthropogenic forcing (in particular, linked to the alteration of coastal ecosystems due to excessive human use) is responsible.

The genus Ostreopsis grows well in shallow water as an epiphyte of macroalgae and dead corals, or covering sand, pebbles and rocks; it also occurs as plankton in the water column. It proliferates mainly attached to surfaces by producing extracellular polysaccharide mucilage derived from pusule fibrous material and mucocysts (see images in GEOHAB 2012 and Honsell et al. 2013). In temperate waters, Ostreopsis species bloom in the summer-autumn seasons (Shears and Ross 2009, Mangialajo et al. 2011) and produce a characteristic rusty-brown-coloured film over the colonized benthic substrate. In addition, high densities of cells swimming freely or embedded in the mucous matrix can be found in the water column and at the air-water interface as floating aggregates.

Ostreopsis proliferations are a serious concern because the PLTX-like group of biotoxins has been implicated in fatal seafood poisonings at tropical latitudes after ingestion of clupeid fishes or crabs (Alcala et al. 1988, Randall 2005) contaminated with bioaccumulated PLTX. To date, fortunately, no Ostreopsis-related food-borne illnesses have been reported in Europe. However, on certain Mediterranean beaches, the presence of the species Ostreopsis cf. ovata has been accompanied by respiratory symptoms and skin and mucosa irritation in humans (see references in Table 1). The affected people had spent some hours, during their recreational or working activities, in beach areas affected by Ostreopsis proliferations, or reside nearby. Acute symptoms include respiratory irritation (rhinorrhea, pharyngeal pain, dry or mildly productive cough, nose irritation), general malaise, headache, fever $\left(\geq 38^{\circ} \mathrm{C}\right.$ ), eye irritation and/or dermatitis (Durando et al. 2007, Tichadou et al. 2010). Most of the symptoms disappeared within a few hours without specific medication when people moved away from the affected area in the vicinity of the Ostreopsis bloom; in only a few severe cases was hospitalization necessary (Durando et al. 2007).

It has been hypothesized that direct contact with seawater containing the microalga and/or with marine aerosols produced during its presence could be the plausible cause of the health disorders. However, the hypothesis has not been confirmed yet for several reasons. First, the profile of clinical manifestations is non-specific, with most cases corresponding to people who were sporadically exposed to marine aerosols and seawater. Hence, the recurrent Ostreopsis blooms are not always accompanied by concomitant symptoms that would generate health reports. This causes underdiagnosis and, thus, under-reporting to the surveillance health system (Tichadou et al. 2010, Pfannkuchen et al. 2012). Second, the estimations of the Ostreopsis concentrations in the affected area were usually conducted only after symptoms were reported. Often, the cell numbers found in plankton are highly variable over short periods (up to two orders of magnitude within few hours; Vila et al. 2008). Thus, the low cell abundances found in plankton on days following the health outbreak hampered our ability to establish a clear relationship between the Ostreopsis blooms and the problems experienced by humans during this study. Third, the nature of the irritative agents has not yet been identified. Although PLTX-like compounds have been suggested as potential agents, the few attempts to detect them in marine aerosols have been inconclusive. In the first study conducted on aerosol samples collected during the Ostreopsis cf. ovata blooms in Sant Andreu de Llavaneres (Catalan coast, NE Spain) in 2009 and 2010 (Casabianca et al. 2013), PLTX-like compounds were not detected, although Ostreopsis cells were identified by molecular tools. In the sampling performed along the Tuscan coast (Italy) in the same years (Ciminiello et al. 2014), a single positive result was obtained. However, this sample was taken in absence of $O$. cf. ovata in the water samples and no toxicological data on PLTXs or PLTX-like compounds by inhalation exposure were conducted in that study.

In the NW Mediterranean, various studies have been conducted on Sant Andreu de Llavaneres beach $\left(41^{\circ} 33.13^{\prime} \mathrm{N} ; 2^{\circ} 29.54^{\prime} \mathrm{E}\right)$, which is an Ostreopsis hot spot where annual blooms have been occurring in the last few decades (Mangialajo et al. 2011, Vila et al. 2012a). At this station, $O$. cf. ovata spans at least two months at high cell abundances $\left(>10^{5}\right.$ cells $\mathrm{g}^{-1}$ of macroalgae fresh weight [FW]) (Vila et al. 2012b). This is very atypical, as blooms in other places along the NW Mediterranean Sea often last for 2 or 3 weeks. The first outbreak in 1998 was associated with benthic fauna mortality (Vila et al. 2008). In the summer of 2004, 74 cases of respiratory disorders were recorded (with up to 200 people potentially affected), coinciding with the presence of the microalgae (Àlvarez et al. 2005, Vila et al. 2008; Table 1). In this case, the causal relationship between symptoms and $O$. cf. ovata was established by chance, because the health problems occurred few days after phytoplankton samples had been taken in the framework of a wider 
Table 1. - Published studies reporting impacts on human health that have been associated with Ostreopsis cf. ovata blooms in the Mediterranean Sea. Cell concentrations refer to the maximum numbers detected in the area, not always coinciding with the health outbreak.

\begin{tabular}{lcccl}
\hline \multicolumn{1}{c}{ Year } & Location & Affected people (n) & Ostreopsis (cells L ${ }^{-1}$ ) & Reference \\
\hline 1998 & NW Med (Spain) & - & $2 \times 10^{5}$ & Vila et al. 2008 \\
$1998,2000,2001$ & Tirrenian (Italy) & $\sim 100$ & - & Sansoni et al. 2003 \\
$2001,2003,2004$ & S Adriatic (Italy) & 28 & - & Gallitelli et al. 2005 \\
2004 & NW Med (Spain) & 74 (estimated 200) & $2 \times 10^{4}$ & Vila et al. 2008, Âlvarez et al. 2005 \\
2005,2006 & Ligurian (Italy) & 228,19 & - & Brescianini et al. 2006, Durando et al. 2007 \\
2006 & NW Med (Spain) & 37 & $2 \times 10^{3}$ & Âlvarez 2006 \\
$2006-2009$ & NW Med (France) & 47 & $>3 \times 10^{4}$ & Tichadou et al. 2010 \\
2006 & SW Med (Spain) & 57 & $1 \times 10^{3}$ & Barroso García et al. 2008 \\
2009 & SW Med (Algeria) & $150-200$ & $8 \times 10^{4}$ & Illoul et al. 2012 \\
2010 & Adriatic (Croatia) & 7 & $4 \times 10^{4}$ & Pfannkuchen et al. 2012 \\
2013 & NW Med (Spain) & 13 & $5 \times 10^{4}$ & This study \\
\hline
\end{tabular}

programme "Monitoring of Harmful Algal Blooms in Catalonia", a contract between ICM-CSIC and the Water Catalan Agency (Generalitat de Catalunya) that controls harmful algal blooms (HABs) along the Catalan coast. Later, in 2006, a new health outbreak affected 37 people in Sant Andreu de Llavaneres (Àlvarez 2006; Table 1). The association with the presence of the microalgae was uncertain, because seawater samples were taken two days after the respiratory irritation was reported and $O$. cf. ovata cell densities in plankton were low (in the order of $2 \times 10^{3}$ cells $\mathrm{L}^{-1}$ ). Subsequent respiratory symptoms, mucosa irritation and wound infections were detected in the population inhabiting, working and/or swimming in this beach area in the summer period but had not been reported. Thus, the direct link with the $O$. cf. ovata blooms remains unclear due to the temporal mismatch between the ecological and the epidemiology studies, as noted earlier (Tichadou et al. 2010, Pfannkuchen et al. 2012).

To clarify this uncertainty, we designed an integrated follow-up epidemiology study in a human population exposed to an Ostreopsis bloom in parallel to the field monitoring of the bloom event. While this study focuses only on respiratory disorders, the outcomes of this research can contribute to the assessment of the general risks to the public health and the environment posed by Ostreopsis outbreaks.

\section{MATERIALS AND METHODS}

\section{Study site and period}

This study was conducted in Sant Andreu de Llavaneres, on the Catalan coast of Spain. The municipality, located $38 \mathrm{~km}$ north of Barcelona, in the Maresme county, has a long, open, shallow sedimentary beach that is heavily colonized by macroalgae. The sedimentary substrate, which extends from the shoreline to at least 5-7 $\mathrm{m}$ depth, is densely colonized by a carpet of macroalgae, mainly Rhodophyceae (Corallina Linnaeus, Jania Lamouroux) and Phaeophyceae (Dictyota Lamouroux, Dilophus Agardh, Halopteris Kützing, Padina Adanson). Chlorophyceae are also present in some restricted areas that receive freshwater seepage from land. This tapestry of macroalgae, crossed by bands of sand parallel to the coastline, constitutes a unique habitat that contrasts with the nearby sandy beaches.
Ostreopsis cf. ovata grows as epiphyte on the macroalgae carpet and is also found swimming freely in the plankton community. In front of this hot spot (at $c a$. $10 \mathrm{~m}$ distance), there is an indoor-outdoor restaurant whose entire staff was selected as the human cohort for our study. The ecological and epidemiological study period extended from 1 June to 1 December 2013, because our former studies in this area (Vila et al. 2008, Vila et al. 2012b, Mangialajo et al. 2011) had shown the seasonality of the Ostreopsis bloom during the summer-autumn period.

\section{Ecological sampling: Ostreopsis monitoring and accompanying parameters}

The abundance of Ostreopsis cells was measured following the regular monitoring procedures applied since 2007 in the area. The protocol takes into consideration that this dinoflagellate can be found as an epiphyte of macroalgae and also swimming in the water column in addition to its preferred water depth for growth.

Marine samples were taken at very shallow (about $20-50 \mathrm{~cm}$ ) depths. Cell numbers in the water column (cells $\mathrm{L}^{-1}$ ) were estimated from natural water samples (ca. $125 \mathrm{ml}$ ) fixed with neutral Lugol's iodine solution and following the Utermöhl $(1931,1958)$ method. Water samples of 10 or $50 \mathrm{~mL}$ (depending on the cell concentration during the bloom development) were settled in sedimentation chambers and counted in a Leica inverted microscope.

Samples for the estimations of epiphytic Ostreopsis were collected from the dominant macroalgae in the mat, which during the 2013 summer were Corallina elongata Ellis \& Solander and Jania rubens (Linnaeus) J.V. Lamouroux. The sample was taken close to the area where the water sample had been previously collected, and a non-perturbed macroalgal mat was chosen. Between 10 and $20 \mathrm{~g}$ of fresh macroalgae were carefully collected and transferred into a $250-\mathrm{mL}$ capacity plastic bottle, to which $180 \mathrm{~mL}$ of in situ and freshly $\mathrm{GF} / \mathrm{F}$ glass fibre-filtered seawater were added. The sample was then vigorously shaken for 1 minute and subsequently sieved through a $200-\mu \mathrm{m}$ mesh. A percolated water subsample (ca. $125 \mathrm{~mL}$ ) containing the microalgae community was fixed with Lugol's iodine solution. The macroalgae were transferred to a glass beaker to measure the exact fresh weight in the laboratory. Cell numbers were estimated using either Sedgewick-Rafter 
or $10-\mathrm{mL}$ sedimentation chambers (depending on the cell densities) in a Leica inverted microscope. Abundances were expressed as cells $\mathrm{g}^{-1} \mathrm{FW}$.

From 15 June to 31 December, in situ water temperature was recorded continuously at 30-minute intervals using a HOBO Water Temperature Pro v2 Data Logger $\left( \pm 0.2^{\circ} \mathrm{C}\right.$ accuracy) (Onset, Cape Cod, Massachusetts) deployed at the sampling point. In addition, discrete water temperature and salinity were measured every sampling day using a WTW microprocessor conductimeter (Model LF197). Meteorology parameters (temperature, humidity, wind velocity and direction, atmospheric pressure and rain) were regularly recorded at a meteorological station located nearby at Port Balís.

\section{Human population}

The staff of the indoor-outdoor restaurant, including ten men and six women, constituted the closed human cohort of our epidemiological study. This group was directly exposed to marine aerosols at least eight hours daily. Many of them had already experienced Ostreopsis-related health symptoms in previous years (Àlvarez 2006).

We designed and provided an epidemiological questionnaire (Supplementary Material, Table S1) containing a list of Ostreopsis-related symptoms similar to the one used elsewhere (Tubaro et al. 2011). Additional information about the health background of each person was also collected. From June to December 2013, all individuals completed a self-administered questionnaire at the end of each working day. Only one person had chronic rhinitis, an ancillary medical problem that could influence the survey results (see Discussion). All participants had expressed their consent to contribute to the epidemiological surveillance according to the ethical procedures of the Public Health Surveillance System of the Autonomous Government of Catalonia.

\section{RESULTS}

\section{Ostreopsis bloom}

During the year, the average air temperature (Fig. 1) increased progressively from February and reached maximum values between the 14 July and the $17 \mathrm{Au}-$ gust $\left(25.5 \pm 0.8^{\circ} \mathrm{C}\right)$. Temperature decreased progressively afterwards, with the lowest values in February $\left(4.6 \pm 0.6^{\circ} \mathrm{C}\right)$. Episodes of high wind intensity $(>15 \mathrm{~m}$ $\mathrm{s}^{-1}$ ) were recorded from November to April (Fig. 1). The lowest-velocity winds blew between 15 June and 26 August $\left(6.1 \pm 2.4 \mathrm{~m} \mathrm{~s}^{-1}\right)$, with the lowest record of $1.6 \mathrm{~m} \mathrm{~s}^{-1}$ on 15 August. The seawater temperature measured from June to December (Fig. 2) showed a similar trend to that of the air, with a slight shift.

The Ostreopsis cf. ovata bloom persisted during the summer-fall months (Figs 1 and 2). The bloom started at the beginning of July, after a long period of increasing temperature, above a threshold of ca. $20^{\circ} \mathrm{C}$ in the air and water and wind intensities below $3 \mathrm{~m} \mathrm{~s}^{-1}$ (on average). The $O$. cf. ovata epiphytic cell population (Figs 1 and 2) grew exponentially, doubling in two days (exponential growth rate of 0.51 divisions day $^{-1}$ ) for almost one month (from July to August). Thereafter, it entered a stationary period with persistent high cell concentrations, from August to mid-October, and then decreased subsequently. In the water, the $O$. cf. ovata planktonic cell population exhibited a similar pattern, with a peak in early August (Fig. 2).

\section{Impacts on human health}

Overall, 13 of 16 people ( $81 \%$ of the studied human population) experienced at least one of the health symptoms listed in the questionnaire over the course of the bloom (as shown in Table 2 and Fig. 2). Eye and nose irritation, rhinorrhea and general malaise were identified as possible Ostreopsis-related health disorders. Usually,
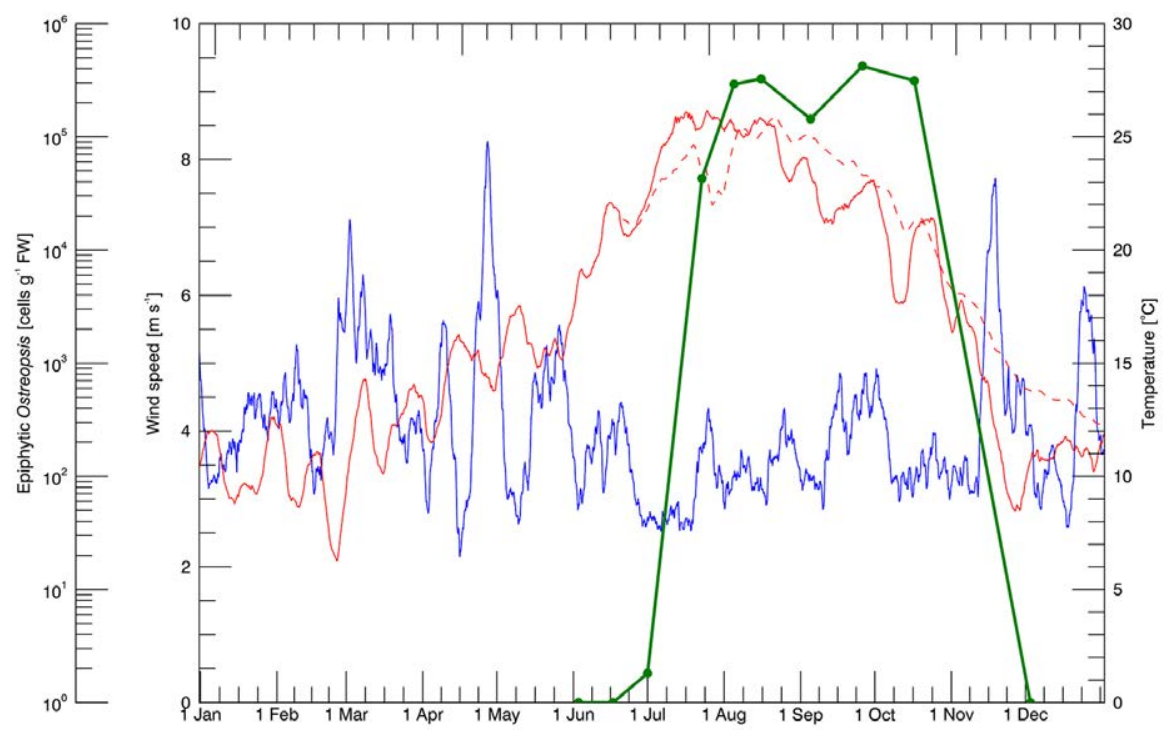

Fig. 1. - Temporal evolution of wind intensity (blue line), air temperature (solid red line) and water temperature (dashed red line) along with the epiphytic concentrations of Ostreopsis cf. ovata (green line) in 2013. The data of the three environmental parameters were low-pass filtered using a cut off period of 7 days (running mean). 

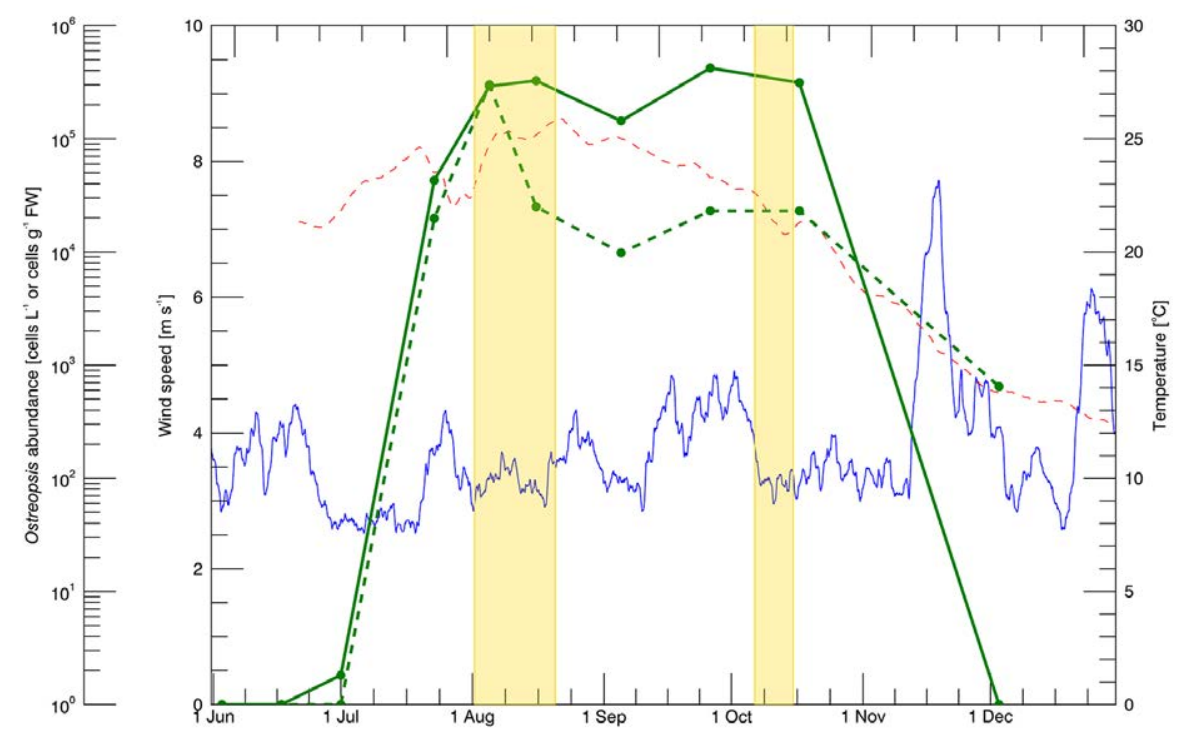

Fig. 2. - Temporal evolution of wind intensity (blue line) and water temperature (dashed red line) along with the epiphytic (solid green line, cells $\mathrm{g}^{-1} \mathrm{FW}$ ) and planktonic (dashed green line, cells $\mathrm{L}^{-1}$ ) concentrations of Ostreopsis cf. ovata in the second half of 2013. Wind and temperature data were low-pass filtered using a cut off period of 7 days (running mean). Painted areas indicate the periods of human health affectation.

these symptoms lasted no more than 3-4 days; in August, one female noticed 7 continuous days of illness. All the staff members continued to work throughout the study period; no one required hospital attention. The period of maximum effect extended from the 4 to 21 August, with the highest numbers between 7 and 10 August. One person experienced rhinorrhea and nose irritation for one week in October. Accordingly, a second health affect extending from 8 to 16 October was defined.

During the first affectation period, water and air temperature ranged between $20^{\circ} \mathrm{C}$ and $25^{\circ} \mathrm{C}$ (Figs 1 and 2). In the second period, the water temperature range was narrower $\left(20-23^{\circ} \mathrm{C}\right)$, and the air temperature dropped below $20^{\circ} \mathrm{C}$. During the two health affect episodes, average wind intensities were relatively low compared with the preceding days (Fig. 2). Wind direction varied markedly, apart from the daily breeze regime displaying a landward and seaward oscillation pattern (not shown). To test the importance of wind direction within each health affect period, the wind measurements were projected onto the direction perpendicular to the coast, with seaward and landward components represented, respectively, by positive and negative values (Fig. 3). The same approach was used for the intermediate period without health affects extending from 22 August to 7 October. The resulting wind components were statistically analysed (Table 3 ). The frequency distribution diagram (Fig. 3) showed similar patterns during the three phases, with a wind component blowing from the sea to land always present. Overall, the variability of the wind intensity perpendicular to the coast was high, but no significant trend characterized any period (Table 3).

Table 2. - Symptoms reported by the human cohort (16 people) during the study.

\begin{tabular}{|c|c|c|c|c|c|c|c|}
\hline Date & Day & Affected people (n) & Eye irritation & Nose irritation & Rhinorrhea & Malaise & Total symptoms \\
\hline \multicolumn{8}{|c|}{ 1st affectation period } \\
\hline $4-8-2013$ & 216 & 4 & - & 3 & 2 & 2 & 7 \\
\hline $6-8-2013$ & 218 & 4 & - & 1 & 3 & 2 & 6 \\
\hline $7-8-2013$ & 219 & 8 & - & 4 & 7 & - & 11 \\
\hline $8-8-2013$ & 220 & 7 & - & 4 & 5 & 1 & 10 \\
\hline $9-8-2013$ & 221 & 8 & - & 5 & 5 & - & 10 \\
\hline $10-8-2013$ & 222 & 11 & 1 & 8 & 3 & - & 12 \\
\hline $15-8-2013$ & 227 & 1 & - & 1 & - & - & 1 \\
\hline $16-8-2013$ & 228 & 4 & - & 4 & 4 & - & 8 \\
\hline $17-8-2013$ & 229 & 2 & - & 1 & 0 & - & 1 \\
\hline $21-8-2013$ & 233 & 1 & - & - & 1 & - & 1 \\
\hline \multicolumn{8}{|c|}{ 2nd affectation period } \\
\hline 8-10-2013 & 281 & 1 & - & 1 & 1 & - & 2 \\
\hline $9-10-2013$ & 282 & 1 & - & 1 & 1 & - & 2 \\
\hline $10-10-2013$ & 283 & 1 & - & 1 & 1 & - & 2 \\
\hline $11-10-2013$ & 284 & 1 & - & 1 & 1 & - & 2 \\
\hline $12-10-2013$ & 285 & 1 & - & 1 & 1 & - & 2 \\
\hline $13-10-2013$ & 286 & 1 & - & 1 & 1 & - & 2 \\
\hline $14-10-2013$ & 287 & 1 & - & 1 & 1 & - & 2 \\
\hline $15-10-2013$ & 288 & 1 & - & 1 & 1 & - & 2 \\
\hline $16-10-2013$ & 289 & 1 & - & 1 & 1 & - & 2 \\
\hline
\end{tabular}


Table 3. - Statistics of the wind intensity in the three main periods established on the basis of the health affectation in summer 2013. Negative average wind velocity values indicate landward winds and positive values indicate seaward ones.

\begin{tabular}{|c|c|c|c|c|c|c|c|}
\hline Period & Dates & $\mathrm{N}$ & Average $\left(\mathrm{m} \mathrm{s}^{-1}\right)$ & Variance & Skewness & Kurtosis & Fraction landward \\
\hline 1st (main) affectation & 4-21 August & 913 & 0.108 & 6.205 & 0.683 & 0.975 & 0.499 \\
\hline No affectation & 22 August - 7 October & 2160 & -0.483 & 12.680 & -0.285 & 1.158 & 0.556 \\
\hline 2nd affectation & 8-16 October & 432 & -0.076 & 11.685 & -1.163 & 1.748 & 0.296 \\
\hline
\end{tabular}

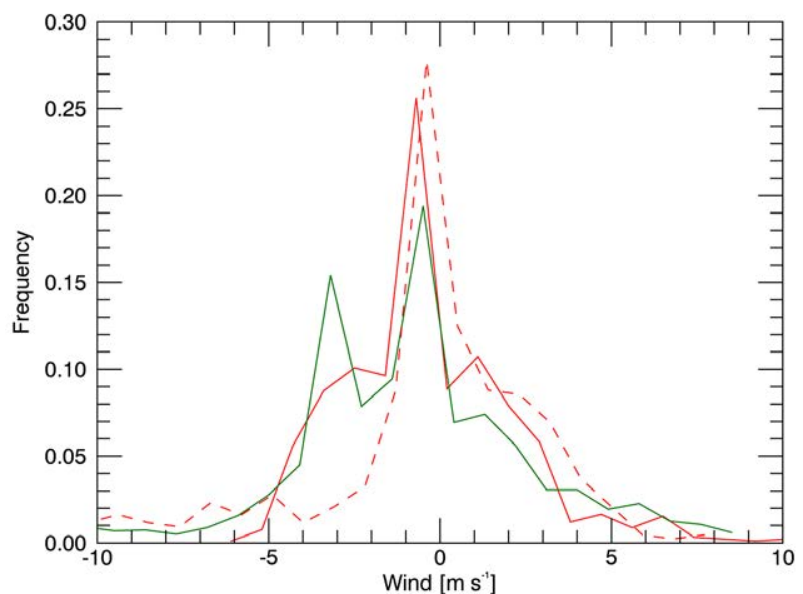

Fig. 3. - Histograms of the wind component perpendicular to the coast corresponding to the first affectation period (solid red line), the intermediate period (green line) and the second affectation period (dashed red line). Negative values indicate landward winds and positive values indicate seaward ones.

\section{DISCUSSION}

Our work constitutes the first monitoring of an Ostreopsis bloom conducted simultaneously and in coordination with prospective epidemiological followup research. The main strengths of our study are that 1) it was conducted on a well-defined human cohort, 2) the cohort followed was permanently exposed to the environmental conditions related to a long-lasting Ostreopsis bloom; and 3) the cohort was monitored for six months, i.e. before, during and after the bloom. Although a larger human cohort would have been epidemiologically suitable, our study fulfilled these three important conditions, which are very difficult to achieve in field studies.

Our results support the existence of a causal link between blooms of this toxic dinoflagellate and certain health impacts on humans. Paradoxically, the health affectation in our study site occurred during only a few days, whereas the Ostreopsis cell proliferation persisted for more than two months. This finding could result from the interaction of complex mechanisms involving meteorological and oceanic conditions, the physiology of Ostreopsis cells and the particular sensitivity of the affected individuals. Our working hypotheses for future studies are discussed next.

In 2013, the Ostreopsis bloom exhibited the typical seasonal pattern described earlier in Sant Andreu de Llavaneres (Mangialajo et al. 2011, Vila et al. 2012a, b). The meteorology conditions during the summer-autumn season fitted within the general climatology described in the area. Cells bloomed exponentially after approximately a two-week period, with temperatures above $20^{\circ} \mathrm{C}$ and relatively calm weather (based on the recorded wind intensities). Overall, cell abundances were in the range reported elsewhere in the area (e.g. Mangialajo et al. 2011, Vila et al. 2012a, b). The epiphytic Ostreopsis cf. ovata population remained for more than two months at high concentrations and within the same order of magnitude $\left(10^{5}\right.$ cells $\mathrm{g}^{-1} \mathrm{FW}$ ). In the water, the cell numbers followed a similar dynamics, although with higher variability (within two orders of magnitude, from $10^{4}$ to $5 \times 10^{5}$ cells L ${ }^{-1}$ ). As described by Vila et al. (2008), high daily variations in the planktonic cell numbers in the water column could be partly due to biological rhythms of cell detachment from the macroalgae. Furthermore, water motion controlled by the major hydrodynamic patterns near the Catalan coast (see e.g. Sabatés et al. 2001, and references there in), combined with the daily breeze regime and swell, would then cause the dilution or concentration of the Ostreopsis planktonic population. As for the epidemiological study in this Ostreopsis hot spot, the observed human cohort suffered a similar attack rate ( $81 \%$ of the studied cohort) to that of the previous reported outbreaks (Àlvarez et al. 2005, Àlvarez 2006, Vila et al. 2008). However, in 2013 the affected people experienced fewer symptoms and of milder intensity than in 2004 and 2006. At present, there is a lack of similar epidemiology studies conducted simultaneously with the ecological monitoring. This lack of data hampers our ability to hypothesize about the factors involved in the interannual variation of the symptoms of human health, so further research is required. The interannual variability of both Ostreopsis bloom intensity and other meteorological and oceanographic conditions may also be at play and will be considered elsewhere.

In the 2013 Ostreopsis bloom that we studied, the health symptoms occurred mainly during a particularly short time window of the event, coinciding with the transition from the exponential to the stationary phase of the Ostreopsis population, with high planktonic and epiphytic cell concentrations. This finding suggests that Ostreopsis cells may produce certain toxic or allergenic substances responsible for the observed symptoms during a specific physiological state coinciding with a specific phase of the bloom. As has been observed in toxin producing microalgae, toxin cell concentrations may vary with the physiological phase as well as in response to environmental forcings (e.g. Bates et al. 1991, Pan et al. 1996, Taroncher-Oldenberg et al. 1997), although the response can be speciesspecific. For instance, in laboratory experiments (Bolli et al. 2007), paralytic shellfish toxin cell content in Alexandrium catenella and A. minutum decreased from the exponential to the stationary phase, and it was also lower under turbulent than calm conditions. 
During the stationary phase of the bloom, in spite of high epiphytic cell numbers until the bloom collapsed, the health impacts were negligible. Only the person affected by allergy exhibited two symptoms potentially related to the Ostreopsis bloom in October (Table 2). In the case of respiratory problems associated with the Karenia brevis blooms in Florida and the Gulf of Mexico, the highest sensitivity to the brevetoxin exposure was evident for children, senior citizens and asthmatics (Fleming et al. 2005, 2007, Kirkpatrick et al. 2011). Similarly, it could be hypothesized that health disorders occur in especially sensitive people during the last stationary phase of the Ostreopsis bloom. Furthermore, we must consider that the permanently exposed human population acquires some sort of immunization after their first exposure period at the beginning of the bloom. Again, the more sensitive individuals would be expected to have a greater tendency to exhibit symptoms towards the end of the bloom. However, this hypothesis should be taken with caution, given that only one person was affected and this second period of sensitivity occurred during the autumn season when it could be associated with other health problems (e.g. viral and bacterial diseases). As already noted, the lack of specificity of the symptoms associated with the presence of $O$. cf. ovata has been a major factor limiting the establishment of the link between blooms and the effects on human health (Tichadou et al. 2010). Testing these hypotheses requires further careful medical studies, including prospective epidemiological tests and larger human cohorts stratified according to different levels of exposure to the sea conditions (HertzPicciotto 1998).

The superimposition of certain meteorological conditions must be necessary for the health symptoms to occur. In particular, landward winds should favour the transport of aerosolized compounds from the seawater to the beach and the nearby inhabited areas, and be involved in the health impacts (Vila et al. 2008, Kirkpatrick et al. 2010). However, no relevant differences concerning the landward wind component during the two affect periods and the days between them were found (Table 3). Our analysis indicates that transport of aerosols containing irritants was possible during all phases of the bloom. This finding reinforces the hypothesis that the irritating compounds are present in the aerosol within a specific phase of the bloom only.

Another fundamental question concerns the process of aerosolization of the potential irritating agents (cells, fragments of cells or toxins, Casabianca et al. 2013). Physical forcing associated with oceanic processes, such as swell (not studied here) and wind-generated turbulence should be major factors. However, we cannot currently establish a specific wind intensity threshold from the values plotted in Figures 1 and 2, because our data treatment smoothed the absolute number and shows average values only. Water motion could interfere with cell detachment from the benthic substrate, favouring the increase of the planktonic cell population, which in turn may be more easily integrated in the aerosol. In this context, the benthic Ostreopsis population would act as a pool for potential human and environmental effects. In contrast, the planktonic fraction, probably more directly related to the aerosolized agents, could constitute a proxy of the actual health impact risk. In our view, any Ostreopsis-related alert risks should be based on both the benthic and planktonic cell abundances. Until now, a threshold of 30000 cells $\mathrm{L}^{-1}$ in the water has been used to define the alert risk in some Mediterranean areas (International Conference on Ostreopsis Development, ICOD 2012, round table discussion; Funari et al. 2015) provided that meteorological and hydrodynamic conditions are favourable to aerosol and spray formation. Above this value, prohibition of beach access and bathing has been recommended by authorities in France. This concentration of cells, however, has not always been accompanied by reports of health impacts (Tichadou et al. 2010). Because beach closures could have had associated negative impacts on tourism-related social and economic activities, prohibitions were subsequently replaced by preventive alerts and by increased public information about the risk of exposure. These management strategies were recently published in Italian guidelines (Funari et al. 2015). In our study, the main period of effect in August coincided with the highest Ostreopsis concentrations recorded in the plankton, above $10^{4}$ cells $\mathrm{L}^{-1}$, and with constant concentrations of around $10^{5}$ cells $\mathrm{g}^{-1} \mathrm{FW}$ in the benthos. Thus, our present study supports the alert threshold based on plankton cell abundances and also provides new arguments to include the epiphytic cells densities above our observed level as well $\left(>10^{5}\right.$ cells $\mathrm{g}^{-1} \mathrm{FW}$ macroalgae). This range is in the order of those discussed at the ICOD 2012 round table discussion. To conclude, however, it is important to understand other unknown factors that might be at play in determining dinoflagellate toxicity. Further investigation is needed to define the factors to be included in any possible alert index. Multidisciplinary research and monitoring are required to prevent or mitigate adverse health effects from exposure to complex aerosolized biotoxins produced by microalgae. In the case of the Karenia brevis, for outbreaks in the coasts of Florida and Gulf of Mexico (Kirkpatrick et al. 2010, 2011, Fleming et al. 2011) this approach was addressed over several years and allowed progress to be made towards the development of early warning systems. Information about the presence of a Florida red tide is now available from the Gulf of Mexico HAB Forecast (NOAA Harmful Algal Bloom Operational Forecast System, https:// tidesandcurrents.noaa.gov/hab/) in conjunction with a local Beach Condition Reporting System.

Ostreopsis recurrent proliferations at temperate latitudes constitute an emergent environmental and public health threat. The potential impacts on human health also include food-borne diseases due to the ingestion of marine products contaminated with PLTX and analogues obtained in the Ostreopsis bloom-affected areas. The Mediterranean strains of Ostreopsis cf. ovata analysed up to now seem to produce only small quantities of a putative PLTX (Ciminiello et al. 2006) and large quantities of other PLTX-like compounds, namely different ovatoxins (e.g. Ciminiello et al. 2008, 2010, Rossi et al 2010). These PLTX-like compounds 
have been detected in Mediterranean marine fauna (Aligizaki et al. 2011, Amzil et al. 2012, Biré et al. 2013, Biré et al. 2015), suggesting the potential risk of biotoxin accumulation in seafood. For this reason, the Panel on Contaminants in the Food Chain (CONTAM Panel) of the European Food Safety Authority (EFSA 2009) assessed the risks to human health associated with the presence of PLTX-group biotoxins in shellfish, although the European regulation to monitor PLTX has not yet become established. Another aspect to consider in the many facets of the toxicity attributed to Ostreopsis is the role of certain bacteria such as Vibrio, some of which are known to be responsible for wound infections in people swimming in marine waters. Bellés-Garulera et al. (2016) found a positive correlation between Vibrio and Ostreopsis abundances in Sant Andreu de Llavaneres during a year cycle, and suggested a likely role of vibrios in injury infections suffered by beach users during the bloom. Future research should combine ecophysiological, toxicological and environmental (water and weather conditions) data and characterizations of the Ostreopsis blooms to unveil the important factors and mechanisms of the impact on human health. All this information will be essential to the development of early warning systems.

\section{ACKNOWLEDGEMENTS}

This study has been was supported by the CTQ200806754-C04-04 (EBITOX) and the CTM2014-53818-R (OstreoRisk) projects of the Spanish Government (MINECO). J. I-F received financial support from the Fundación General CSIC (Programa ComFuturo). We kindly acknowledge all the collaboration received in Sant Andreu de Llavaneres by the Aceña family and all the staff at the Restaurant Pins Mar, and the Club Nàutic El Balís, which provided the meteorological data used in this study. This work contributes to the implementation of the objectives of the SCOR and IOC/UNESCO-funded programmes GEOHAB and GlobalHAB. The authors thank the Drs. P.A. Tester and R. Lemée, whose comments and suggestions greatly improved the final version of the manuscript.

\section{REFERENCES}

Alcala A.C., Alcala L.C., Garth J.S., et al. 1988. Human fatality due to ingestion of the crab Demania reynaudii that contained a palytoxin-like toxin. Toxicon 26: 105-107. http://dx.doi.org/10.1016/0041-0101(88)90142-0

Aligizaki K., Nikolaidis G. 2006. The presence of the potentially toxic genera Ostreopsis and Coolia (Dinophyceae) in the North Aegean Sea, Greece. Harmful Algae 5: 717-730. http://dx.doi.org/10.1016/j.hal.2006.02.005

Aligizaki K., Katikou P., Milandri A., et al. 2011. Occurrence of palytoxin-group toxins in seafood and future strategies to complement the present state of the art. Toxicon 57: 390-399. http://dx.doi.org/10.1016/j.toxicon.2010.11.014

Àlvarez J. 2006. Internal document of the Public Health Surveillance System of the Autonomous Government of Catalonia.

Àlvarez J., Pedrol A., Parrón I., et al. 2005. Brote Epidémico de sintomatología irritativa en Sant Andreu de Llavaneres: ¿el origen está en el mar? In: Proceedings of the XXIII Reunión de la Sociedad Española de Epidemiología, Las Palmas de Gran Canaria, Spain. Gaceta Sanitaria 19(Supl. 1): 3-139.

Amzil Z., Sibat M., Chomérat N., et al. 2012. Ovatoxin-a and palytoxin accumulation in seafood in relation to Ostreopsis cf. ovata blooms on the French Mediterranean coast. Mar. Drugs 10: 477-496.

http://dx.doi.org/10.3390/md10020477

Barroso García P., Rueda de la Puerta P., Parrón Carreno T., et al. 2008. Brote con síntomas respiratorios en la provincia de Almería por una posible exposición a microalgas toxicas. Gaceta Sanitaria 22: 578-584. http://dx.doi.org/10.1016/S0213-9111(08)75357-3

Bates S.S., de Freitas A.S.W., Milley J.E., et al. 1991. Controls on domoic acid production by the diatom Nitzschia pungens f. multiseries in culture: nutrients and irradiance. Can. J. Fish. Aquat. Sci. 48: 1136-1144. http://dx.doi.org/10.1139/f91-137

Bellés-Garulera J., Vila M., Borrull E., et al. 2016.Variability of planktonic and epiphytic vibrios in a coastal environment affected by Ostreopsis blooms. Sci. Mar. 80S1: 97-106. http://dx.doi.org/10.3989/scimar.04405.01A

Biré R., Trotereau S., Lemée R., et al. 2013. Occurrence of palytoxins in marine organisms from different trophic levels of the French Mediterranean coast harvested in 2009. Harmful Algae 28: $10-22$. http://dx.doi.org/10.1016/j.hal.2013.04.007

Biré R., Trotereau S., Lemée R., et al. 2015. Hunt for Palytoxins in a wide variety of marine organisms harvested in 2010 on the French Mediterranean coast. Mar. Drugs 13: 5425-5446. http://dx.doi.org/10.3390/md13085425

Bolli L., Llaveria G., Garcés E., et al. 2007. Modulation of ecdysal cyst and toxin dynamics of two Alexandrium (Dinophyceae) species under small-scale turbulence. Biogeosciences 4: 559-567.

http://dx.doi.org/10.5194/bg-4-559-2007

Brescianini C., Grillo C., Melchiorre N., et al. 2006. Ostreopsis ovata algal blooms affecting human health in Genova, Italy, 2005 and 2006. Euro Surveillance 11: E060907.

Casabianca S., Casabianca A., Riobó P., et al. 2013. Quantification of the toxic dinoflagellate Ostreopsis spp. by qPCR assay in marine aerosol. Environ. Sci. Technol. 47: 3788-3795. http://dx.doi.org/10.1021/es305018s

Ciminiello P., Dell'Aversano C., Fattorusso E., et al. 2006. The Genoa 2005 outbreak. Determination of putative palytoxin in Mediterranean Ostreopsis ovata by a new liquid chromatography tandem mass spectrometry method. Anal. Chem. 78: 6153-6159.

http://dx.doi.org/10.1021/ac060250j

Ciminiello P., Dell'Aversano C., Fattorusso E., et al. 2008. LC-MS/ MS and HRMS/MS data demonstrated the presence of putative palytoxin and the novel ova- toxin-a in plankton collected during the Ligurian 2006 toxic outbreak. J. Am. Soc. Mass Spectrom. 19: 111-120. http://dx.doi.org/10.1016/j.jasms.2007.11.001

Ciminiello P., Dell'Aversano C., Dello Iacovo E., et al. 2010. Complex palytoxin-like profile of Ostreopsis ovata. Identification of four new ova-toxins by high-resolution liquid chromatography/mass spectrometry. Rapid Commun. Mass Spectrom. 24: 2735-2744. http://dx.doi.org/10.1002/rcm.4696

Ciminiello P., Dell'Aversano C., Dello Lacovo E., et al. 2014. First finding of Ostreopsis cf. ovata toxins in marine aerosols. Environ. Sci. Technol. 48: 3532-3540. http://dx.doi.org/10.1021/es405617d

Durando P., Ansaldi F., Oreste P., et al. 2007. Ostreopsis ovata and human health: epidemiological and clinical features of respiratory syndrome outbreaks from a two-year syndromic surveillance, 2005-2006, in north-west Italy. Eurosurveillance 12: 1-4.

EFSA Panel on Contaminants in the Food Chain (CONTAM). 2009. Scientific opinion on marine biotoxins in shellfish-Palytoxin group. EFSA J. 1393: 1-38.

Fleming L.E., Kirkpatrick B., Backer L.C., et al. 2005. Initial evaluation of the effects of aerosolized Florida red tide toxins (brevetoxins) in persons with asthma. Environm. Health Persp. 113: 650-657. http://dx.doi.org/10.1289/ehp.7500

Fleming L.E., Kirkpatrick B., Backer L.C., et al. 2007. Aerosolized Red Tide Toxins (Brevetoxins) and Asthma. Chest 131: 187-194. http://dx.doi.org/10.1378/chest.06-1830

Fleming L.E., Kirkpatrick B., Backer L.C., et al. 2011. Review of Florida red tide and human health effects. Harmful Algae 10: 224-233. http://dx.doi.org/10.1016/j.hal.2010.08.006 
Funari E., Manganelli M., Testai E. 2015. Ostreospis cf. ovata blooms in coastal water: Italian guidelines to assess and manage the risk associated to bathing waters and recreational activities. Harmful Algae 50: 45-56. http://dx.doi.org/10.1016/j.hal.2015.10.008

Gallitelli M., Ungaro N., Addante L.M., et al. 2005. Respiratory illness as a reaction to tropical algal blooms occurring in a temperate climate. J. Am. Med. Ass. 293: 2599-2600.

GEOHAB 2012. Global Ecology and Oceanography of Harmful Algal Blooms, In: Berdalet E., Tester P., Zingone A. (eds), GEOHAB Core Research Project: HABs in Benthic Systems. IOC of UNESCO and SCOR, Paris and Newark, 64 pp.

Hertz-Picciotto I. 1998. Environmental Epidemiology. In: Rothman K.J., Greenland S. (eds) Modern epidemiology. Second edition. Lippincott Williams and Wilkins, pp. 555-561.

Honsell G., Bonifacio A., De Bortoli M., et al. 2013. New insights on cytological and metabolic features of Ostreopsis cf. ovata Fukuyo (Dinophyceae): A multidisciplinary approach. PLoS One 8: e57291.

http://dx.doi.org/10.1371/journal.pone.0057291

ICOD. 2012. Round Table 2 of the International Conference on $O s$ treopsis Development: Environmental, Health and Economic management, state of the art and perspectives, Cryptogamie, Algologie 33: 85-87.

http://dx.doi.org/10.7872/crya.v33.iss2.2011.085

Illoul H., Rodríguez F., Vila M., et al. 2012. The genus Ostreopsis along the Algerian coastal waters (SW Mediterranean Sea) associated with a human respiratory intoxication episode. Cryptogamie, Algologie 33: 209-216.

http://dx.doi.org/10.7872/crya.v33.iss2.2011.209

Kirkpatrick B., Pierce R., Cheng Y.S., et al. 2010. Inland transport of aerosolized Florida red tides. Harmful Algae 9: 186-189. http://dx.doi.org/10.1016/j.hal.2009.09.003

Kirkpatrick B., Fleming L.E., Bean J.A., et al. 2011. Aerosolized red tide toxins (brevetoxins) and asthma: continued health effects after $12 \mathrm{~h}$ beach exposure. Harmful Algae 10: 138-143. http://dx.doi.org/10.1016/j.hal.2010.08.005

Mangialajo L., Ganzin N., Accoroni S., et al. 2011. Trends in Ostreopsis proliferation along the Northern Mediterranean coasts. Toxicon 57: 408-420. http://dx.doi.org/10.1016/j.toxicon.2010.11.019

Pan Y., Subba Rao D.V., Mann K.H., et al. 1996. Effects of silicate limitation on production of domoic acid, a neurotoxin, by the diatom Pseudo-nitzschia multiseries. I. Batch culture studies. Mar. Ecol. Prog. Ser. 131: 225-233. http://dx.doi.org/10.3354/meps131225

Pfannkuchen M., Godrijan J., Pfannkuchen D.M., et al. 2012. Toxinproducing Ostreopsis cf. ovata are likely to bloom undetected along coastal areas. Environ. Sci. Technol. 46: 5574-5582. http://dx.doi.org/10.1021/es300189h

Randall J.E. 2005. Review of clupeotoxism, an often fatal illness from the consumption of clupeoid fishes. Pacif. Sci. 59: 73-77. http://dx.doi.org/10.1353/psc.2005.0013

Rhodes L. 2011. World-wide occurrence of the toxic dinoflagellate genus Ostreopsis Schmidt. Toxicon 57: 400-407. http://dx.doi.org/10.1016/j.toxicon.2010.05.010

Rossi R., Castellano V., Scalco E., et al. 2010. New palytoxin-like molecules in Mediterranean Ostreopsis cf. ovata (dinoflagellates) and in Palythoa tuberculosa detected by liquid chromatography-electrospray ionization time-of-flight mass spectrometry. Toxicon 56: 1381-1387. http://dx.doi.org/10.1016/j.toxicon.2010.08.003

Sabatés A., Salat J., Olivar M.P. 2001. Advection of continental water as an export mechanism for anchovy, Engraulis encrasicolusi, larvae. Sci. Mar. 65(Suppl. 1): 77-87.

Selina M.S., Orlova T.Y. 2010. First occurrence of the genus Ostreopsis (Dinophyceae) in the Sea of Japan. Bot. Mar. 53: 243-249. http://dx.doi.org/10.1515/BOT.2010.033

Sansoni G., Borghini B., Camici G., et al. 2003 Fioriture algali di Ostreopsis ovata (Gonyaulacales: Dinophyceae): un problema emergente. Biologia Ambientale 17: 17-23.

Shears N.T., Ross P.M. 2009. Blooms of benthic dinoflagellates of the genus Ostreopsis; an increasing and ecologically important phenomenon on temperate reefs in New Zealand and worldwide. Harmful Algae 8: 916-925. http://dx.doi.org/10.1016/j.hal.2009.05.003

Taroncher-Oldenburg G., Kulis D.M., Anderson D.M. 1997. Toxin variability during the cell cycle of the dinoflagellate Alexandrium fundyense. Limnol. Oceanogr. 42: 1178-1188. http://dx.doi.org/10.4319/1o.1997.42.5_part_2.1178

Tichadou L., Glaizal M., Armengaud A., et al. 2010. Health impact of unicellular algae of the Ostreopsis genus blooms in the Mediterranean Sea: Experience of the French Mediterranean coast surveillance network from 2006 to 2009. Clin. Toxicol. 48: 839-844.

http://dx.doi.org/10.3109/15563650.2010.513687

Tubaro A., Durando P., Del Favero G., et al. 2011. Case definitions for human poisonings postulated to palytoxins exposure. Toxicon 57: 478-495. http://dx.doi.org/10.1016/j.toxicon.2011.01.005

Utermöhl H. 1931. Neue Wege in der quantitativen Erfassung des Planktons (mit besonderer Berücksichtigung des Ultraplanktons). Verh. int. Ver. theor. angew. Limnol. 5: 567-596.

Utermöhl H. 1958. Zur Vervollkomnung der quantitativen Phytoplankton-Methodik. Mitt. int. Ver. ther. angew. Limnol. 9: 1-38.

Vila M., Garcés E., Masó M. 2001. Potentially toxic epiphytic dinoflagellate assemblages on macroalgae in the NW Mediterranean. Aquat. Microb. Ecol. 26: 51-60.

Vila M., Masó M., Sampedro N. et al. 2008. The genus Ostreopsis in recreational waters of the Catalan Coast and Balearic Islands (NW Mediterranean Sea): is this the origin of human respiratory difficulties? In: Moestrup $\varnothing$. et al. (eds), Proceedings of the 12th International Conference on Harmful Algae, Copenhagen, Denmark, 4-8 September 2006. ISSHA and IOC of UNESCO, pp. 334-336.

Vila M., Arin L., Battocchi C., et al. 2012a. Management of Ostreopsis blooms in recreational waters along the Catalan coast (NW Mediterranean Sea): cooperation between a research project and a monitoring program. Cryptogamie, Algologie 33: $143-152$. http://dx.doi.org/10.7872/crya.v33.iss2.2011.143

Vila M., Riobó P., Bravo I., et al. 2012b. A three-year time series of toxic Ostreopsis blooming in a NW Mediterranean coastal site: preliminary results. In: Pagou P. and Hallegraeff G. (eds). Proceeding of the 14th International Conference on Harmful Algae. ISSHA and IOC of UNESCO, pp. 111-113.

\section{SUPPLEMENTARY MATERIAL}

The following material is available through the online version of this article and at the following link: http://www.icm.csic.es/scimar/supplm/sm04395esm.pdf

Table S1. - Daily health questionnaire notebook. 